\title{
Artificial selection of reaction norms of wing pattern elements in Bicyclus anynana
}

\author{
GRAHAM J. HOLLOWAY $\ddagger^{*}$ \& PAUL M. BRAKEFIELD $\ddagger$ \\ †Department of Pure and Applied Zoology, AMS Building, University of Reading, Whiteknights, PO Box 228, Reading \\ RG6 2AJ, U.K. and $\ddagger$ Section of Evolutionary Biology, Institute of Evolutionary and Ecological Sciences, University of \\ Leiden, Schelpenkade 14a, 2313 ZT Leiden, The Netherlands
}

\begin{abstract}
A novel use of selection was applied to the examination of the genetics of phenotypic plasticity. The approach provides a sensitive way of detecting genotype-environment $(\mathrm{g} \times \mathrm{e})$ interactions and also allows the form of any interactions across an environmental gradient to be investigated through changes in the shapes of the reaction norms. The wing pattern of the butterfly $B$. anynana varies with season; eyespot size increases with development temperature. Selection lines to increase and to decrease eyespot size at $28^{\circ} \mathrm{C}$ were carried out. The effect of selection on the eyespot reaction norms with temperature was examined. Selection produced divergent reaction norms across the entire range of temperature in most eyespots. Significant $g \times e$ interactions were sometimes present but the degree of interaction was always relatively small. When present, the form of the interaction varied between the sexes. There was a high degree of genetic independence between the eyespots on the ventral and on the dorsal wing surfaces, except in the dorsal eyespot in the wing cell corresponding to the wing cell of the selected ventral wing surface eyespot. The significance of the results for the maintenance of genetic variation in B. anynana is considered.
\end{abstract}

Keywords: B. anynana, genetics, plasticity, reaction norm, selection, wing pattern.

\section{Introduction}

Many animals live in seasonal environments and are exposed regularly to a variety of conditions. It is often proposed that a phenotype optimal in one season is suboptimal in another season. Under these circumstances, there would be strong selection favouring the evolution of the ability to produce different phenotypes in response to the changing seasons. The ability of a single genotype to produce different phenotypes in response to a environmental gradient is called phenotypic plasticity (Bradshaw, 1965; Williams, 1966; Sultan, 1987; West-Eberhard, 1989). Many studies describe examples of phenotypic plasticity and the possible consequences for fitness (e.g. Dodson, 1974, 1989; Schlichting, 1989; David et al., 1990; Spitze, 1992; Strathmann et al., 1992; Gebhardt \& Stearns, 1993a,b; Weeks, 1993). Most of these studies have been laboratory based and few examples of phenotypic plasticity have been considered under field conditions. Exceptions include the work of Brambilla (1980) and Parejko \& Dodson (1991) using Daphnia pulex, Brakefield \& Reitsma (1991) using Bicyclus anynana, and

*Correspondence.
Holloway (1993) using several species of Eristalis hoverflies.

The tropical African butterfly Bicyclus anynana Butler (Lepidoptera, Satyrinae) shows wet/dry seasonal variation in a variety of ventral surface wing pattern elements, as do many of the other 80 species (Condamin, 1973) in the genus (J. C. Roskam, personal communication). For example, the size of the eyespots on the ventral margins of the fore- and hindwings increases with developmental temperature (Brakefield \& Reitsma, 1991; Windig, 1992). It is thought that large eyespots in 'wet season' animals serve to deflect the attacks of vertebrate predators during the period of breeding activity. In the dry season, there are few opportunities for breeding and the wing eyespots on individuals emerging from pupae at the start of this period are very small to enhance the cryptic pattern required to rest undetected on the dry brown leaves that litter the forest floor (Brakefield \& Larsen, 1984).

Cases where the phenotype varies with season, for example spring and summer broods of certain butterfly species (e.g. Polygonia c-album (Nylin, 1989) and Araschnia levana (Koch, 1992)) that are phenotypically distinct, are referred to as seasonal polyphenisms (Shapiro, 1976; Stearns, 1989). Stearns (1989) limits 
the use of reaction norms (Wolterek, 1909; Schmalhausen, 1949; Stearns \& Koella, 1986) to continuous changes in a character's value in response to an environmental gradient. B. anynana and B. safitza both show seasonally determined phenotypic variation but it is clear that the wing patterns of both species can change continuously with temperature (Brakefield \& Reitsma, 1991; Windig, 1992), so it is appropriate to refer to reaction norms in the case of Bicyclus wing patterns.

The theory of the genetics of plasticity and the associated reaction norm (Wolterek, 1909; Schmalhausen, 1949; Stearns \& Koella, 1986) has been developed in some detail (e.g. de Jong, 1990a,b; Gabriel \& Lynch, 1992; Gavrilets \& Scheiner, 1993a,b). The genetic variance of plasticity can be equated with genotypeenvironment $(\mathrm{g} \times \mathrm{e})$ interactions (Via \& Lande, 1985, 1987) and this component of variation has been estimated for a variety of experimental systems (Via, 1984; Groeters \& Dingle, 1987; Newman, 1988; Wade, 1990; Rawson \& Hilbish, 1991; Hughes, 1992; Platenkamp \& Shaw, 1992). Significant $\mathrm{g} \times \mathrm{e}$ interactions have frequently been found. Another approach has been to measure the heritability of plasticity (e.g. Scheiner \& Lyman, 1989; Ebert et al., 1993; Windig, 1993). Although the statistical analysis of these results remains a problem (Scheiner \& Lyman, 1989; Scheiner et al., 1991), the best measure of heritability in this case is the variation of slopes of linear reaction norms divided by the total variation in slopes (de Jong, 1990a). However, there are very few data available to indicate the shapes of reaction norms (van Noordwijk \& Gebhardt, 1987; Gavrilets \& Scheiner, 1993a,b) and, furthermore, many studies have considered the phenotype in only two environments (Groeters \& Dingle, 1987; Newman, 1988; Hillesheim \& Stearns, 1991; Kingsolver \& Wiernasz, 1991; Ebert et al., 1993; Hill \& Gatehouse, 1993). Where more than two environments have been considered the resulting reaction norms are sometimes approximately linear (e.g. Weiss \& Gorman, 1990; Rawson \& Hilbish, 1991), but often not (e.g. Gupta \& Lewontin, 1982; Windig, 1993). Selection experiments have also been carried out to reduce or increase the range of plasticity (Scheiner \& Lyman, 1991; Hillesheim \& Stearns, 1991).

The purpose of the present study was to investigate aspects of the genetics of plasticity in wing pattern in $B$. anynana. We developed a selection procedure to generate the necessary data. If the reaction norms of different genotypes cross extensively, a significant $\mathrm{g} \times \mathrm{e}$ interaction occurs (van Noordwijk, 1989). The more the reaction norms intersect in a random manner the lower the genetic correlation among environments (Via, 1984), consequently selection in one environment would be expected to have a limited effect on phenotype expression in another environment. If a comparison of reaction norms from divergent lines selected under constant environmental conditions shows a nonsignificant line by environment interaction, this would indicate that the same genes were operating with similar effects in the various environments, i.e. no $\mathrm{g} \times \mathrm{e}$ interaction (Via \& Lande, 1985; Falconer, 1989). On the other hand, the reaction norms may diverge, cross or display some other form of line by environment interaction so that $\mathrm{g} \times \mathrm{e}$ interaction could be inferred. Genetic variance components, such as $\mathrm{g} \times \mathrm{e}$ inter actions, are difficult to measure precisely. An advantage of the approach described here is that it allows mean values to be compared which can be measured precisely with much smaller sample sizes. The specific goals of the study were: (i) to determine how artificial selection under warm conditions influences character expression under cool conditions in $B$. anynana; (ii) to examine the effect of artificial selection on ventral surface pattern elements in comparison with correlated changes in the characters on the dorsal wing surfaces; and (iii) to investigate how artificial selection in one environment affects the shapes of the reaction norms.

\section{Materials and methods}

Rearing methods are described in detail in Holloway et al. (1993a). Two selection lines were established at $28^{\circ} \mathrm{C}$ : one to produce large eyespots in the second position (second eyespot) of the ventral surface of the forewing (high line) and one to produce small second eyespots (low line) (see Fig. 1 in Holloway et al., 1993a). The size of the eyespot was closely correlated with the size of the butterfly, so selection was carried out on the ratio of the second eyespot to the length of the forewing. Ratios were taken rather than residuals about a regression line in order to ensure that all butterflies had an equal chance of being selected, irrespective of size. After 10 generations of selection on the high line and seven generations of selection on the low line the two lines had diverged substantially from each other (Holloway et al., 1993a) and selection was terminated.

Newly hatched larvae produced by the adults which came from the last generations of the two selection lines were distributed over four temperatures $\left(17^{\circ} \mathrm{C}\right.$, $20^{\circ} \mathrm{C}, 23^{\circ} \mathrm{C}$ and $28^{\circ} \mathrm{C}$ ) to obtain reaction norms of the various wing pattern elements against temperature. These temperatures represent approximately the normal mean monthly range experienced by the butterflies under field conditions in Malawi (Brakefield \& Reitsma, 1991). Ideally, one would wish to obtain bundles of reaction norms (van Noordwijk, 1989), 
each reaction norm derived from a single family. However, previous work has shown that it is very difficult to get pairs of $B$. anynana to mate in isolation and also females may mate more than once. Consequently, the butterflies were mass reared so that the mean effect of selection on the 'population' reaction norm could be assessed.

For each line, at least 100 pairs of butterflies were placed into a mesh cage $(50 \times 50 \times 50 \mathrm{~cm})$ and for each selection line two replicates were established. The butterflies were kept at $28^{\circ} \mathrm{C} \pm 1^{\circ} \mathrm{C}$ and 85 per cent \pm 5 per cent relative humidity. The adult butterflies in each cage were provided with food (mashed banana) and six small maize plants on which to deposit eggs. The maize plants were removed daily and replaced with new plants. After 4 days of oviposition the adult females had laid thousands of eggs and after this time period no more eggs were collected. The eggs took 4 days to hatch at $28^{\circ} \mathrm{C}$ and the hatchlings were randomly distributed over the four experimental temperatures. The larvae were placed into mesh cages and fed with approximately 3-week-old maize plants. The plants were renewed when almost completely defoliated and the length of time between renewal depended on the size of the larvae. Newly formed pupae were allowed to develop undisturbed in the cage and freshly emerged adults were removed and transferred to a freezer for storage until analysis. The development period from egg hatch to adult emergence and the sex were recorded.

Six wing characters were measured using a Wild binocular microscope: length of left forewing, the widths of the second and fifth eyespots on the ventral surface of the left forewing, the width of the fifth eyespot on the ventral surface of the left hindwing and the widths of the second and fifth eyespots on the dorsal surface of the left forewing. All statistical analyses were carried out using Minitab. Because mortality varied among the temperatures, the final data set was imbalanced. Analyses of variance $(F)$ were carried out using GLM.

\section{Results}

A total of 951 adult butterflies were reared that were in good condition for analysis $\left(169\right.$ at $17^{\circ} \mathrm{C}, 224$ at $20^{\circ} \mathrm{C}$, 350 at $23^{\circ} \mathrm{C}$ and 208 at $28^{\circ} \mathrm{C}$ ). The sex ratio was biased (353 males and 598 females) and there was significant heterogeneity across the temperatures $\left(\chi_{3}^{2}=14.3\right.$, $P<0.01)$, principally caused through a low percentage of males at $28^{\circ} \mathrm{C}$. We have, at present, no explanation for this observation.

Windig (1992) showed that the wing pattern in $B$. safitza was more closely related to the logarithm $(\log )$ of development period than to developmental temperature, suggesting that the proximate cue for wing pattern was integrated into development period. This was also true for females in the present study and $\log$ development period frequently explained over 30 per cent of the variation in spot size. There was no difference in the amount of variation explained by log development period and temperature in males. However, development period and temperature were very closely related (males: $r=-0.89, P<0.001$; females: $r=-0.864, P<0.001)$ and we were concerned with an examination of the reaction norms which, by definition, refer to phenotypic value on environmental variable (Wolterek, 1909; Schmalhausen, 1949; Bradshaw, 1965), so analyses were carried out with reference to temperature and not development period.

As wing pattern is closely related to the development period, the selection procedure could have simply selected for short and long development periods rather than for the wing pattern itself. Table 1 shows the mean development periods for males and females at the various temperatures. It is clear that selection influenced the development period and that the high line always had a shorter average development period than the low line (males: $F_{4,345}=9.8, P<0.001$; females: $\left.F_{4,575}=109.7, P<0.001\right)$. However, for a given development period the high and low lines did not produce the same wing pattern, indicating that genes coding for the various wing pattern elements independent of development were also selected (van Oosterhout et al., 1993).

Table 1 shows the mean wing lengths of the two sexes reared under the various temperatures. Males were significantly smaller than females $\left(F_{1,950}=1099.2\right.$, $P<0.001)$, but for neither sex was there an effect of selection on wing length (males: $F_{1,352}=0.88$, not significant (NS); females: $F_{1,596}=3.21$, NS). For both sexes there was variation in wing length across temperature $(P<0.001)$ with, generally, larger insects being produced at lower temperatures. Wing length was correlated with the size of eyespots at all positions on the wing surface within each temperature (e.g. wing length vs. second forewing ventral eyespot at $28^{\circ} \mathrm{C}$ : males: average $r=0.42, P<0.05$; females: average $r=0.33, P<0.05)$. In order to compensate for this the analyses below were carried out on the ratio of eyespot width to wing length.

The width of the second eyespot on the ventral surface of the forewing over forewing length was the character to which selection was applied. There was a large effect of selection on the ratio in both sexes (males: $\quad F_{1,352}=882.7$; females: $F_{1,396}=1407.4$; $P<0.001$ in both cases) and substantial variation across temperatures (males: $F_{3,350}=148.4$; females: 
Table 1 Values for males and females from the high $(\mathrm{H})$ and low $(\mathrm{L})$ selection lines of Bicyclus anynana at four temperatures for development period (dev), wing length (wing), second and fifth ventral forewing eyespot widths (2spotv and 5spotv, respectively), fifth ventral hindwing eyespot width ( 5 spoth) and the second and fifth dorsal forewing eyespots widths ( 2 spotd and 5 spotd, respectively)

\begin{tabular}{|c|c|c|c|c|c|c|c|c|}
\hline \multirow[b]{3}{*}{ Sex } & \multicolumn{8}{|c|}{ Temperature } \\
\hline & \multicolumn{2}{|c|}{$17^{\circ} \mathrm{C}$} & \multicolumn{2}{|c|}{$20^{\circ} \mathrm{C}$} & \multicolumn{2}{|c|}{$23^{\circ} \mathrm{C}$} & \multicolumn{2}{|c|}{$28^{\circ} \mathrm{C}$} \\
\hline & $\mathrm{H}$ & L & $\mathrm{H}$ & $\mathrm{L}$ & $\mathrm{H}$ & $\mathrm{L}$ & $\mathrm{H}$ & $\mathrm{L}$ \\
\hline \multicolumn{9}{|l|}{ Dev } \\
\hline Males & $\begin{array}{c}80.45 \\
( \pm 1.75)\end{array}$ & $\begin{array}{c}81.61 \\
( \pm 0.79)\end{array}$ & $\begin{array}{c}47.56 \\
( \pm 0.90)\end{array}$ & $\begin{array}{c}51.02 \\
( \pm 0.51)\end{array}$ & $\begin{array}{c}35.67 \\
( \pm 0.28)\end{array}$ & $\begin{array}{c}37.99 \\
( \pm 0.31)\end{array}$ & $\begin{array}{c}24.97 \\
( \pm 0.39)\end{array}$ & $\begin{array}{c}29.82 \\
( \pm 0.45)\end{array}$ \\
\hline Females & $\begin{array}{c}86.43 \\
( \pm 0.66)\end{array}$ & $\begin{array}{c}102.05 \\
( \pm 1.54)\end{array}$ & $\begin{array}{c}50.05 \\
( \pm 0.59)\end{array}$ & $\begin{array}{c}53.85 \\
( \pm 0.46)\end{array}$ & $\begin{array}{c}36.65 \\
( \pm 0.22)\end{array}$ & $\begin{array}{c}39.23 \\
( \pm 0.30\rangle\end{array}$ & $\begin{array}{c}25.31 \\
( \pm 0.18)\end{array}$ & $\begin{array}{c}30.56 \\
( \pm 0.27)\end{array}$ \\
\hline \multicolumn{9}{|l|}{ Wing } \\
\hline Males & $\begin{array}{c}19.52 \\
( \pm 0.17)\end{array}$ & $\begin{array}{c}19.26 \\
( \pm 0.11)\end{array}$ & $\begin{array}{c}19.46 \\
( \pm 0.19)\end{array}$ & $\begin{array}{c}19.27 \\
( \pm 0.10)\end{array}$ & $\begin{array}{c}19.14 \\
( \pm 0.01)\end{array}$ & $\begin{array}{c}18.79 \\
( \pm 0.09)\end{array}$ & $\begin{array}{c}18.73 \\
( \pm 0.15)\end{array}$ & $\begin{array}{c}19.15 \\
( \pm 0.20)\end{array}$ \\
\hline Females & $\begin{array}{c}21.43 \\
( \pm 0.18)\end{array}$ & $\begin{array}{c}21.36 \\
( \pm 0.11)\end{array}$ & $\begin{array}{c}21.67 \\
( \pm 0.12)\end{array}$ & $\begin{array}{c}21.34 \\
( \pm 0.10)\end{array}$ & $\begin{array}{c}21.14 \\
( \pm 0.11)\end{array}$ & $\begin{array}{c}20.97 \\
( \pm 0.09)\end{array}$ & $\begin{array}{c}21.39 \\
( \pm 0.12)\end{array}$ & $\begin{array}{r}21.30 \\
( \pm 0.15)\end{array}$ \\
\hline Males & $\begin{array}{c}1.00 \\
( \pm 0.05)\end{array}$ & $\begin{array}{c}0.21 \\
( \pm 0.03)\end{array}$ & $\begin{array}{c}1.37 \\
( \pm 0.11)\end{array}$ & $\begin{array}{c}0.38 \\
( \pm 0.03)\end{array}$ & $\begin{array}{c}1.83 \\
( \pm 0.06)\end{array}$ & $\begin{array}{c}0.50 \\
( \pm 0.02)\end{array}$ & $\begin{array}{c}2.27 \\
( \pm 0.06)\end{array}$ & $\begin{array}{r}1.12 \\
( \pm 0.05)\end{array}$ \\
\hline Females & $\begin{array}{c}1.11 \\
( \pm 0.07)\end{array}$ & $\begin{array}{c}0.34 \\
( \pm 0.02)\end{array}$ & $\begin{array}{c}1.80 \\
( \pm 0.09)\end{array}$ & $\begin{array}{c}0.66 \\
( \pm 0.03)\end{array}$ & $\begin{array}{c}2.19 \\
( \pm 0.05)\end{array}$ & $\begin{array}{c}0.85 \\
( \pm 0.02)\end{array}$ & $\begin{array}{c}2.62 \\
( \pm 0.04)\end{array}$ & $\begin{array}{r}1.21 \\
( \pm 0.03)\end{array}$ \\
\hline \multicolumn{9}{|l|}{5 spotv } \\
\hline & $( \pm 0.08)$ & $( \pm 0.06)$ & $( \pm 0.16)$ & $( \pm 0.04)$ & $\begin{array}{c}3.25 \\
( \pm 0.07)\end{array}$ & $\begin{array}{c}1.95 \\
( \pm 0.05)\end{array}$ & $\begin{array}{c}3.42 \\
( \pm 0.01)\end{array}$ & $\begin{array}{c}3.09 \\
( \pm 0.07)\end{array}$ \\
\hline Females & $\begin{array}{c}3.41 \\
( \pm 0.11)\end{array}$ & $\begin{array}{c}2.43 \\
( \pm 0.06)\end{array}$ & $\begin{array}{c}4.27 \\
( \pm 0.10)\end{array}$ & $\begin{array}{c}3.21 \\
( \pm 0.06)\end{array}$ & $\begin{array}{c}4.43 \\
( \pm 0.06)\end{array}$ & $\begin{array}{c}3.64 \\
( \pm 0.04)\end{array}$ & $\begin{array}{c}4.77 \\
( \pm 0.07)\end{array}$ & $\begin{array}{r}3.90 \\
( \pm 0.05)\end{array}$ \\
\hline Males & $\begin{array}{c}1.49 \\
( \pm 0.06)\end{array}$ & $\begin{array}{c}0.95 \\
( \pm 0.03)\end{array}$ & $\begin{array}{c}1.97 \\
( \pm 0.11)\end{array}$ & $\begin{array}{c}1.10 \\
( \pm 0.03)\end{array}$ & $\begin{array}{c}2.24 \\
( \pm 0.05)\end{array}$ & $\begin{array}{c}1.30 \\
( \pm 0.03)\end{array}$ & $\begin{array}{c}2.69 \\
( \pm 0.07)\end{array}$ & $\begin{array}{r}2.10 \\
( \pm 0.06)\end{array}$ \\
\hline Females & $\begin{array}{c}1.64 \\
( \pm 0.08)\end{array}$ & $\begin{array}{c}0.89 \\
( \pm 0.03)\end{array}$ & $\begin{array}{c}2.41 \\
( \pm 0.10)\end{array}$ & $\begin{array}{c}1.40 \\
( \pm 0.04)\end{array}$ & $\begin{array}{c}2.84 \\
( \pm 0.06)\end{array}$ & $\begin{array}{c}1.80 \\
( \pm 0.04)\end{array}$ & $\begin{array}{c}3.30 \\
( \pm 0.06)\end{array}$ & $\begin{array}{c}2.28 \\
( \pm 0.05)\end{array}$ \\
\hline Males & $\begin{array}{c}1.26 \\
( \pm 0.07)\end{array}$ & $\begin{array}{r}0.20 \\
( \pm 0.07)\end{array}$ & $\begin{array}{c}1.57 \\
( \pm 0.07)\end{array}$ & $\begin{array}{c}0.42 \\
( \pm 0.05)\end{array}$ & $\begin{array}{c}1.60 \\
( \pm 0.04)\end{array}$ & $\begin{array}{c}0.53 \\
( \pm 0.05)\end{array}$ & $\begin{array}{c}1.97 \\
( \pm 0.08)\end{array}$ & $\begin{array}{r}1.15 \\
( \pm 0.06)\end{array}$ \\
\hline Females & $\begin{array}{c}1.64 \\
( \pm 0.06)\end{array}$ & $\begin{array}{c}0.45 \\
( \pm 0.05)\end{array}$ & $\begin{array}{c}1.97 \\
( \pm 0.06)\end{array}$ & $\begin{array}{c}0.98 \\
( \pm 0.05)\end{array}$ & $\begin{array}{c}2.00 \\
( \pm 0.03)\end{array}$ & $\begin{array}{c}1.00 \\
( \pm 0.49)\end{array}$ & $\begin{array}{c}2.28 \\
( \pm 0.04)\end{array}$ & $\begin{array}{c}1.49 \\
( \pm 0.04)\end{array}$ \\
\hline \multicolumn{9}{|l|}{5 spotd } \\
\hline Males & $\begin{array}{c}2.43 \\
( \pm 0.08)\end{array}$ & $\begin{array}{c}2.40 \\
( \pm 0.06)\end{array}$ & $\begin{array}{c}2.53 \\
( \pm 0.02)\end{array}$ & $\begin{array}{c}2.37 \\
( \pm 0.05)\end{array}$ & $\begin{array}{c}2.53 \\
( \pm 0.07)\end{array}$ & $\begin{array}{c}2.39 \\
( \pm 0.03)\end{array}$ & $\begin{array}{c}2.82 \\
( \pm 0.12)\end{array}$ & $\begin{array}{c}2.74 \\
( \pm 0.07)\end{array}$ \\
\hline Females & $\begin{array}{c}3.64 \\
( \pm 0.09)\end{array}$ & $\begin{array}{c}3.48 \\
( \pm 0.05)\end{array}$ & $\begin{array}{c}3.86 \\
( \pm 0.08)\end{array}$ & $\begin{array}{c}3.77 \\
( \pm 0.04)\end{array}$ & $\begin{array}{c}3.76 \\
( \pm 0.06)\end{array}$ & $\begin{array}{c}3.69 \\
( \pm 0.03)\end{array}$ & $\begin{array}{c}4.11 \\
( \pm 0.06)\end{array}$ & $\begin{array}{c}3.87 \\
( \pm 0.05)\end{array}$ \\
\hline
\end{tabular}

The development period is in days from egg hatch to emergence from pupa and the lengths and widths are in $\mathrm{mm}$.

Standard errors about the means are attached.

$F_{3,594}=239.9 ; P<0.001$ in both cases; Table 1). There was also a line $\times$ temperature interaction (males: $F_{3,350}=13.87$; females: $F_{3,594}=19.78 ; P<0.001$ in both cases), indicating a degree of independence of gene expression among the various temperatures (Fig. 1a). It can be seen from Fig. 1a that the interaction in females occurred through a narrowing of the distance between the high and low selected norms towards cooler temperatures. The male mean reaction norms were furthest apart at $23^{\circ} \mathrm{C}$.

The other two ventral wing surface eyespot ratios showed large correlated responses to selection in both sexes (fifth eyespot forewing males: $F_{1,352}=298.3$ and females: $F_{1,596}=412.9$; fifth eyespot hindwing males: $F_{1,351}=364.6$ and females: $F_{1,595}=593.2 ; P<0.001$ in all cases) and also varied across temperatures (fifth 
Fig. 1 Reaction norms of the sizes of a variety of eyespots relative to forewing length for both sexes (-: females) of Bicyclus anynana on the ventral (a: 2 nd eyespot forewing, b: 5 th eyespot forewing, c: 5 th eyespot hindwing) and dorsal (d: 2 nd eyespot forewing, e: 5th eyespot forewing) wing surfaces against developmental temperature for the high $(0)$ and low $(\bullet)$ lines (see text).

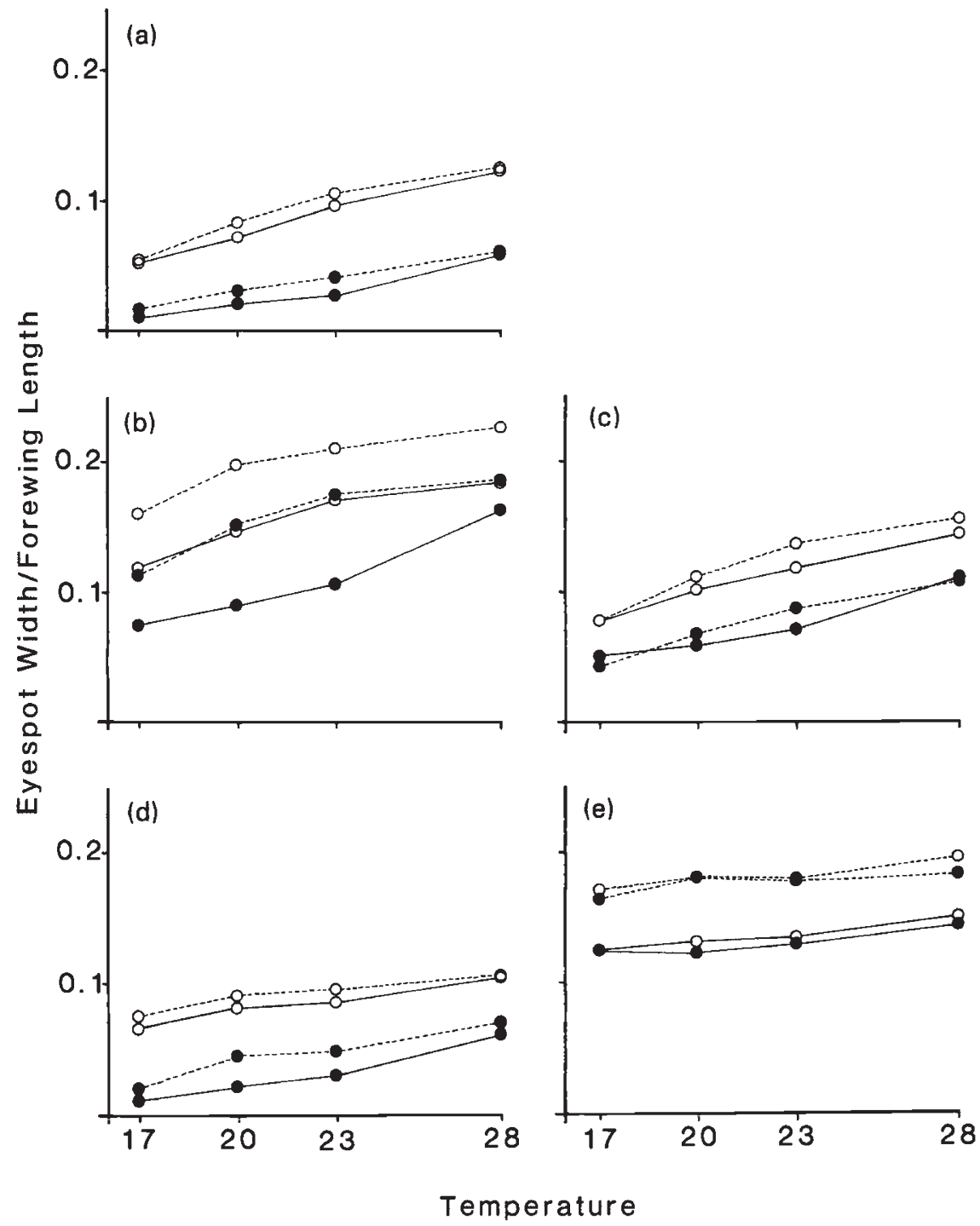

$P<0.001$; females: $\left.F_{3,592}=92.4, \quad P<0.001\right)$. The females showed a significant line $\times$ temperature interaction $\left(F_{3,592}=5.3, P<0.002\right)$ whereas the males did $\operatorname{not}\left(F_{3,346}=1.2\right.$, NS; Fig. $\left.1 \mathrm{~d}\right)$.

The fifth dorsal surface eyespot ratio was different from all the other wing components examined in that the eyespot in females showed only a limited effect of selection $\left(F_{1,596}=8.3, P<0.005\right)$ and in males no effect at all $\left(F_{1,350}=2.9\right.$, NS; Fig. 1e). In both sexes there was variation across temperature (males: $F_{3,348}=10.5$, $P<0.001$; females: $F_{3,594}=22.7, P<0.001$ ), but in neither sex was there a line $\times$ temperature interaction (males: $F_{3,348}=0.4$, NS; females: $F_{3,594}=2.0, \mathrm{NS}$ ).

\section{Discussion}

It has long been argued that phenotypic plasticity can be adaptive and, therefore, subject to the effects of

\begin{abstract}
natural selection (e.g. Bradshaw, 1965; Caswell, 1983;
\end{abstract}
$P<0.001$; females: $\left.F_{1,594}=843.0, P<0.001\right)$ and also varied across temperature (males: $F_{3,346}=48.4$, 
Schlichting, 1986; Scheiner, 1993; Schlichting \& Pigliucci, 1993; Windig, 1993). This implies that genes exist which influence plasticity, although not everybody agrees with this latter point (Via, 1993). Recently, much attention has been directed towards examining the genetic basis of plasticity. This can be complicated using quantitative genetics (Scheiner \& Lyman, 1989; Scheiner et al., 1991) and also suffers, as do all estimates of genetic variance and covariance, from large standard errors. Given this, it is sometimes more realistic to aim to demonstrate the presence of genetic variation for plasticity than to try to quantify it with precision.

The approach used here is somewhat different from selection to increase or decrease plasticity, in that selection was only carried out in one environment. The subsequent change in the position, slope and shape of the mean reaction norm indicates whether the genes selected remain operational across the entire environmental gradient. One statistical advantage of this type of approach is that the identification of the parameters of interest is not hampered by large standard errors. Furthermore, the analysis does not rely on the assumption that the reaction norms are linear, which in reality is not always the case (see Introduction). A possible disadvantage is that selection experiments continue for many generations whereas a split family analysis can be performed in one or two generations. The organism used here, $B$. anynana, was attractive because it carried wing pattern characters for which the function is well described (Brakefield \& Larsen, 1984), so that we were confident that we were dealing with adaptively plastic characters. Some other studies have been concerned with characters such as thorax size in Drosophila (e.g. Scheiner \& Lyman, 1989, 1991; Weber \& Scheiner, 1992) and the function in the wild of this variation with temperature is less well understood, although species like Drosophila clearly have certain advantages for selection experiments.

All eyespots on the ventral surface showed significant responses to selection which resulted in the reaction norms of the sizes of the eyespots relative to wing length separating across their entire length. As pointed out by Holloway et al. (1993a), selection for eyespot size probably occurred at two levels: genes coding for the reaction of cells in a localized area to the concentration of eyespot-forming morphogens and on genes affecting the production or denaturation of these morphogens (Nijhout, 1980, 1990, 1991; French \& Brakefield, 1992). The relative size of the second eyespot on the ventral surface was selected and selection here would have influenced genes at both levels. The heritability of this eyespot is estimated to be over 0.4 (Holloway et al., 1993a) and, consequently, there was a rapid response to selection. There was also a substantial line $\times$ temperature (i.e. $\mathrm{g} \times \mathrm{e}$ ) interaction in both sexes. In $B$. anynana and $B$. safitza, the eyespot reaction norms with temperature are continuous (Brakefield \& Reitsma, 1991; Windig, 1992, respectively) and not bounded at extremes of environmental tolerance (Gabriel \& Lynch, 1992). However, it is also clear that if selection were continued in this system, the selection line for small eyespots would encounter a lower boundary in that eyespots smaller than zero cannot be produced. If this occurred, a line $\times$ temperature interaction might exist that need not reflect a $\mathrm{g} \times \mathrm{e}$ interaction, although very few zero eyespots were noted in the present study so we are confident that the data here have not been influenced significantly. Also, there is no evidence that the low selection line levels off at $17^{\circ} \mathrm{C}$ (Fig. 1a) which supports this assertion.

The other two ventral eyespots that were examined showed large correlated responses to selection (Fig. 1b, c). It can be argued that this correlated response probably occurred as a result of selection for genes responsible for the control of the mechanism that produces eyespots, which is common to all eyespots, at least on the ventral wing surface (French \& Brakefield, 1992). The females showed no line $\times$ temperature interaction for either pair of reaction norms whereas the males did in both cases. Interestingly, the form of the interaction was the same for these two eyespot ratios as for the selected ratio, namely that the widest point between the reaction norms occurred at $23^{\circ} \mathrm{C}$. This suggests that the genetics of plasticity for wing pattern characters differs between the sexes. It is the case that males are generally much darker than females and thermoregulatory behaviour is probably more important in males (Windig, 1992, 1993). Indeed, in the present study there was always a significant positional difference between reaction norms with respect to sex. Developmental constraints are often sex-dependent (Maynard Smith et al., 1985) and, in other systems, a substantial amount of sex-limited gene expression has been found (Holloway et al., 1993b). Given this, it is not impossible that sex-limited differences in the $\mathrm{g} \times \mathrm{e}$ interaction could evolve.

The appearance of the dorsal wing surface is different from the ventral surface and it might be that there is a difference in the way in which eyespots are formed (Holloway et al., 1993a). If this is the case, one may expect to see only a weak correlated response of the dorsal eyespots to selection. With the fifth eyespot (but not the second) on the dorsal surface in males this expectation was wholly fulfilled; there was no effect of selection and no line $\times$ temperature interaction. In females, there was an effect of selection, although very small, and again no interaction. This result demon- 
strates that the sets of genes governing variation in the size of the dorsal fifth eyespot are largely independent of those affecting variation in ventral surface eyespots, at least at $28^{\circ} \mathrm{C}$ under the conditions of selection.

Weber (1992) showed that genes can effect very small localized areas of insect wings, so that the selection procedure carried out here could have resulted in changes only in the region of cell 2 on the ventral and dorsal wing surfaces. These genes had, more or less, similar effects across the environmental gradient used here. The results suggesting a two level genetic control of eyespot development and some independence of the mechanisms determining eyespots on the two wing surfaces (Holloway et al., 1993a) are supported by work on eyespot formation in $B$. anynana (A. Monteiro, personal communication).

Although $\mathrm{g} \times \mathrm{e}$ interactions and, therefore, genetic variation for plasticity were often demonstrated for the relative eyespot sizes, it is clear from Fig. 1 that the amounts of variation explained by the interaction components were always very small. Cases of significant interaction explained on average less than 1 per cent of the total phenotypic variation. The results imply that the population studied here has relatively little genetic variation available that would enable a given genome to produce a very large eyespot in the wet season and a very small eyespot in the dry season or vice versa. There is evidence to suggest that large eyespots in the dry season are heavily selected against in $B$. safitza and Melanitis leda (N. Reitsma, personal communication), so it could be that most of the genetic variation for plasticity has been eroded through natural selection, thus constraining the evolution of an optimal solution to the environmental variability (Gomulkiewicz \& Kirkpatrick, 1992). If larger $\mathrm{g} \times \mathrm{e}$ interactions existed there would be more scope for further or more rapid evolution towards a state where a genotype could attain an optimal solution under a range of conditions (Via \& Lande, 1985; Stearns \& Koella, 1986; de Jong, 1990a).

The role played by $g \times e$ interactions in maintaining polygenic variation has been modelled by Via \& Lande (1987) and Gillespie \& Turelli (1989). In the first case, it was concluded that $\mathrm{g} \times \mathrm{e}$ interactions would not contribute to the maintenance of genetic variation if an optimal reaction norm could evolve. Gillespie \& Turelli (1989) pointed out that $g \times e$ interactions could contribute significantly to the maintenance of genetic variation if no one genotype was most fit in all environments. The heritability of eyespot size in $B$. anynana is in excess of 40 per cent (Holloway et al., 1993a). The fluctuating selection pressures that each genotype experiences with changing season could contribute to the maintenance of such high levels of herita- bility in $B$. anynana. The theory of the maintenance of genetic variation via cyclical selection has been well explored (Hartl, 1980 and references therein) and is relevant here as a result of the low levels of $g \times e$ interactions, which would constrain the evolution of an optimal solution.

\section{Acknowledgements}

We are very grateful to Stans Kofman for her help with the selection of the lines and to Els Schlatman and her colleagues for growing maize for the larvae. Jack Windig and two anonymous referees provided useful comments to improve the manuscript.

\section{References}

BRADSHAW, A. D. 1965. Evolutionary significance of phenotypic plasticity in plants. Adv. Genet., 13, 115-155.

BRAKEFIELD, P. M. AND LARSON, T. B. 1984. The evolutionary significance of dry and wet season forms in some tropical butterflies. Biol. J. Linn. Soc., 22, 1-12.

BRAKEFIELD, P. M. AND REITSMA, N. 1991. Phenotypic plasticity, seasonal climate and the population biology of Bicyclus butterflies (Satyridae) in Malawi. Ecol. Entomol., 16, 291-303.

BRAMBILLA, D. J. 1980. Seasonal changes in size at maturity in small pond Daphnia. In: Kerkfoot, W. C. (ed.) Evolution and Ecology of Zooplankton Communities, pp. 438-455. Hanover, NH.

CASWELL, H. 1983. Phenotypic plasticity in life-history traits: demographic effects and evolutionary consequences. Am. Zool., 23, 35-46.

CONDAMIN, M. 1973. Monographie du genre Bicyclus (Lepidoptera Satyridae). Memoires de l'Institut Fondamental d'Afrique Noire, no. 88, Ifan-Dakar.

DAVID, J. R., CAPY, P. AND GAUTHIER, J.-P. 1990. Abdominal pigmentation and growth temperature in Drosophila melanogaster: similarities and differences in the norms of reaction of successive segments. J. Evol. Biol., 3, 429-445.

DODSON, S. 1. 1974. Adaptive change in plankton morphology in response to size-selection predation: a new hypothesis of cyclomorphosis. Limnol. Oceanogr., 19, 721-729.

DODSON, S. 1. 1989. Predator-induced reaction norms. Bioscience, 39, 447-452.

EBERT, D., YAMPOLSKY, L. AND VAN NOORDWIJK, A. J. 1993. Genetics of life history in Daphnia magna. II. Phenotypic plasticity. Heredity, 70, 344-352.

FALCONER, D. S. 1989. Introduction to Quantitative Genetics, 3rd edn, p. 438. Longman, Harlow, UK.

FRENCH, v. AND BRAKEFIELD, P. M. 1992. The development of eyespot patterns on butterfly wings: morphogen sources or sinks? Development, 116, 103-109.

GABRIEL, W. AND LYNCH, M. 1992. The selective advantage of reaction norms for environmental tolerance. J. Evol. Biol., 5, 41-59. 
GAVRILETS, S. AND SCHEINER, S. M. 1993a. The genetics of phenotypic plasticity. V. Evolution of reaction norm shape. J. Evol. Biol., 6, 31-48.

GAVRILETS, S. AND SCHEINER, S. M. 1993b. The genetics of phenotypic plasticity. VI. Theoretical predictions for directional selection. J. Evol. Biol., 6, 49-68.

GEBHARDT, M. D. AND STEARNS, S. C. 1993a. Phenotypic plasticity for life history traits in Drosophila melanogaster. I. Effect on phenotypic and environmental correlations. J. Evol. Biol., 6, 1-16.

GeBhaRd, M. D. AND STEARNS, S. C. 1993b. Phenotypic plasticity for life history traits in Drosophila melanogaster. II. Epigenetic mechanisms and the scaling of variances. $J$. Evol. Biol., 6, 17-29.

GILLESPIE, J. H. AND TURELLI, M. 1989. Genotype-environment interactions and the maintenance of polygenic variation. Genetics, 121, 129-138.

GOMULKIEWICZ, R. AND KIRKPATRICK, M. 1992. Quantitative genetics and the evolution of reaction norms. Evolution, 46, 390-411.

GROETERS, F. R. AND DINGLE, H. 1987. Genetic and maternal influences on life history plasticity in response to photoperiod by milkweed bugs (Oncopeltus fasciatus) Am. Nat., 129, 332-346.

GUPTA, A. P. AND LEWONTIN, R. C. 1982. A study of reaction norms in natural populations of Drosophila pseudoobscura. Evolution, 36, 934-948.

HARTL, D. L. 1980. Principles of Population Genetics. Sinauer Associates, Sunderland, MA.

HILL, J. K. AND GATEHOUSE, A. G. 1993. Phenotypic plasticity and geographical variation in the pre-reproductive period of Autographa gamma (Lepidoptera: Noctuidae) and its implications for migration in this species. Ecol. Entomol., 18, 39-46.

HILLESHEIM, E. AND STEARNS, S. C. 1991. The responses of Drosophila melanogaster to artificial selection on body weight and its phenotypic plasticity in two larval food environments. Evolution, 45, 1909-1923.

HOLLOWAY, G. J. 1993. Phenotypic variation in colour pattern and seasonal plasticity in Eristalis hoverflies (Diptera: Syrphidae). Ecol. Entomol., 18, 209-217.

HOLLOWAY, G. J., BRAKEFIELD, P. M. AND KOFMAN, S. 1993a. The genetics of wing pattern elements in the polyphenic butterfly, Bicyclus anynana. Heredity, 70, 179-186.

HOLLOWAY, G. J., DE JONG, P. W. AND OTTENHEIM, M. 1993b. The genetics and cost of chemical defense in the two-spot ladybird (Adalia bipunctata L.) Evolution, 47, 1229-1239.

HUGHES, D. J. 1992. Genotype-environment interactions and relative clonal fitness in a marine bryozoan. J. Anim. Ecol., 61, 291-306.

DE JONG, G. 1990a. Quantitative genetics of reaction norms. J. Evol. Biol., 3, 447-468.

DE JONG, G. 1990b. Genotype by environment interaction and the genetic covariance between environments: multilocus genetics. Genetica, 81, 171-177.

KINGSOLVER, J. G. AND WIERNASZ, D. C. 1991. Seasonal polyphenism in wing-melanin pattern and thermoregulatory adaptation in Pieris butterflies. Am. Nat., 137, 816-830. косн, Р. в. 1992. Seasonal polyphenism in butterflies: a hormonally controlled phenomenon of pattern formation. Zool. Jb. Physiol., 96, 227-240.

MAYNARD SMITH, J., BURIAN, R., KAUFFMAN, S., ALBERCH, P., CAMBELL, J., GOODWIN, B., LANDE, R., RAUP, D. AND WOLPERT, L. 1985. Developmental constraints and evolution. $Q$. Rev. Biol., 60, 265-287.

NEWMAN, R. A. 1988. Adaptive plasticity in development of Scaphiopus couchii tadpoles in desert ponds. Evolution, 42, 774-783.

NIJноUT, н. F. 1980. Pattern formation on lepidopteran wings: determination of an eyespot. Devel. Biol., 80, 267-274.

NIJHOUT, H. F. 1990. A comprehensive model for colour pattern formation in butterflies. Proc. R. Soc. B, 239, 81-113.

NIJHOUT, H. F. 1991. The Development and Evolution of Butterfly Wing Patterns. Smithsonian Institute Press, Washington and London.

NYLIN, S. 1989. Effects of changing photoperiods in the life cycle regulation of the comma butterfly, Polygonia c-album (Nymphalidae). Ecol. Entomol., 14, 209-218.

PAREJKo, K. AND DODSON, S. I. 1991. The evolutionary ecology of an antipredator reaction norm: Daphnia pulex and Chaoborus americanus. Evolution, 45, 1665-1674.

PlATENKAMP, G. A. J. AND SHAW, R. G. 1992. Environmental and genetic constraints on adaptive population differentiation in Anthoxanthum odoratum. Evolution, 46, 341-352.

RAWSON, P. D. AND HILBISH, T. J. 1991. Genotype-environment interaction for juvenile growth in the hard clam Mercenaria mercenaria (L.) Evolution, 45, 1924-1935.

SCHEINER, S. M. 1993. Plasticity as a selectable trait: reply to Via. Am. Nat., 142, 371-373.

SCHEINER, S. M., CAPLIN, R. L. AND LYMAN, R. F. 1991. The genetics of phenotypic plasticity. III. Genetic correlations and fluctuating asymmetries. J. Evol. Biol., 4, 51-68.

SCHEINER, S. M. AND LYMAN, R. F. 1989. The genetics of phenotypic plasticity. I. Heritability. J. Evol. Biol., 2, 95-107.

SCHEINER, S. M. AND LYMAN, R. F. 1991. The genetics of phenotypic plasticity. II. Response to selection. J. Evol. Biol., 4, 23-50.

SCHLICHTING, C. D. 1986. The evolution of phenotypic plasticity in plants. Ann. Rev. Ecol. Syst., 17, 667-693.

SCHLICHTING, C. D. 1989. Phenotypic plasticity in Phlox. II. Plasticity of character correlations. Oecologia, 78, 496-501.

SCHLICHTING, C. D. AND PIGLIUCCI, M. 1993. Control of phenotypic plasticity via regulatory genes. Am. Nat., 142, 366-370.

SCHMAlhausen, I. I. 1949. Factors of Evolution. Blakiston, Philadelphia.

SHAPIRo, A. M. 1976. Seasonal polymorphism, Evol. Biol., 9, 259-333.

SPITZE, K. 1992. Predator-mediated plasticity of prey life history and morphology: Chaoborus americanus predation on Daphnia pulex. Am. Nat., 139, 229-247.

STEARNS, S. C. 1989. The evolutionary significance of phenotypic plasticity. Bioscience, 39, 436-445.

STEARNS, S. C. AND KOELLA, J. C. 1986. The evolution of phenotypic plasticity in life-history traits: predictions of reaction 
norms for age and size at maturity. Evolution, 40, 893-913.

STRATHMANN, R. R., FENAUX, L. AND STRATHMANN, M. F. 1992. Heterchronic developmental plasticity in larval sea urchins and its implications for evolution of nonfeeding larvae. Evolution, 46, 972-986.

SULTAN, S. E. 1987. Evolutionary implications of phenotypic plasticity in plants. Evol. Biol., 20, 127-178.

VAN NOORDWIJK, A. J. 1989. Reaction norms in genetical ecology. Bioscience, 39, 453-458.

VAN NOORDWIJK, A. J. AND GEBHARDT, M. 1987. Reflections on the genetics of quantitative traits with continuous environmental variation. In: Loeschcke, V. L. (ed.) Genetic Constraints to Adaptive Evolution, pp. 73-90. Springer, Berlin.

VAN OOSTERHOUT, C., BRAKEFIELD, P. M. AND KOOI, R. E. 1993. Phenotypic plasticity and life history traits in selection lines of Bicyclus anynana. Proc. Exp. Appl. Entomol., 4, 163-168.

VIA, s. 1984. The quantitative genetics of polyphagy in an insect herbivore. I. Genotype-environment interaction in larval performance on different host plant species. Evolution, 38, 881-895.

VIA, S. 1993. Adaptive phenotypic plasticity: target or byproduct of selection in a variable environment? Am. Nat., 142, 352-365.

VIA, S. AND LANDE, R. 1985. Genotype-environment interaction and the evolution of phenotypic plasticity. Evolution, 39, 505-522.

VIA, S. AND LANDE, R. 1987. Evolution of genetic variability in a spatially heterogeneous environment: effects of genotype-environment interaction. Genet. Res., 49, 147-156.

WADE, M. J. 1990. Genotype-environment interaction for climate and competition in a natural population of flour beetles, Tribolium castaneum. Evolution, 44, 2004-2011.

WEBER, K. E. 1992. How small are the smallest selectable domains of form? Genetics, 130, 345-353.

WEBER, S. L. AND SCHEINER, S. M. 1992. The genetics of phenotypic plasticity. IV. Chromosomal localization. J. Evol. Biol., 5, 109-120.

WEEKS, S. C. 1993. Phenotypic plasticity of life history traits in clonal and sexual fish (Poeciliopsis) at high and low densities. Oecologia, 93, 307-314.

WEIS, A. E. AND GORMAN, W. L. 1990. Measuring selection on reaction norms: an exploration of the Eurosta - Solidago system. Evolution, 44, 820-831.

WEST-EBERHARD, M. J. 1989. Phenotypic plasticity and the origins of diversity. Ann. Rev. Ecol. Syst., 80, 249-278.

wiNDIG, J. J. 1992. Seasonal polyphenism in Bicyclus safitza: a continuous reaction norm. Neth. J. Zool., 42, 583-594.

WINDIG, J. J. 1993. The Genetic Background of Plasticity in Wing Pattern of Bicyclus Butterflies. Ph.D. Thesis, University of Leiden.

williams, G. c. 1966. Adaptation and Natural Selection. Princeton University Press, Princeton, NJ.

WOLTEREK, R. 1909. Weitere experimentelle Untersuchungen über Artveränderung, speziell über das Wesen quantitativer Artenunterschiede bei Daphniden. Verh. D. Tsch. Zool. Ges., 1909, 110-172. 